Tropical Journal of Pharmaceutical Research September 2020; 19 (9): 1985-1991

ISSN: $1596-5996$ (print); 1596-9827 (electronic) (C) Pharmacotherapy Group, Faculty of Pharmacy, University of Benin, Benin City, 300001 Nigeria.

\title{
Chemical composition of the volatile oil of Chenopodium ambrosioides L. from Mianyang in Sichuan Province of China and its sub-chronic toxicity in mice
}

\author{
Jiao Li, Xiao Yang, Jing Yu, Zhimin Li, Qiuyue Deng, Yanling Cao, Xiu Chen, \\ Hong Zhang, Yu Wang* \\ College of Life Science, Sichuan Normal University, Chengdu 610101, China
}

*For correspondence: Email: 744489314@qq.com; Tel: +86-2884760596

Sent for review: 29 April 2020

Revised accepted: 29 August 2020

\begin{abstract}
Purpose: To determine the chemical constituents of the volatile oil of Chenopodium ambrosioides $L$. from Mianyang in Sichuan Province of China, and assess the sub-chronic toxicity of the volatile oil in mice.

Methods: The volatile chemical components were analyzed by gas chromatography-mass spectrometry (GC-MS). Sixty Kunming mice were divided into six groups of ten mice each. One group served as control (no treatment), two groups were orally administered $\rho$-cymene at doses of 3 and $7 \mathrm{mg} / \mathrm{kg}$, respectively, for 27 days, while three groups received the volatile oil at doses of 10, 25 and $40 \mathrm{mg} / \mathrm{kg}$, respectively, for the same duration. Sub-chronic toxicity in the mice was evaluated by observing their general behavior, measuring serum levels of aspartate transaminase (AST) and alanine transaminase $(A L T)$, evaluating liver, heart, kidney and thymus indices, and assessing the histological morphology of the organs.

Results: The volatile oil contained 14 chemical components, of which $\alpha$-terpinene and $\rho$-cymene accounted for 32.89 and $24.25 \%$, respectively. The volatile oil caused significant $(p<0.05)$ increase in liver index, and serum AST and ALT levels, and also induced distinct morphological changes in mouse liver, heart and kidney.

Conclusion: The main volatile components of the oil are $\alpha$-terpinene and $\rho$-cymene. The volatile oil showed dose-dependent toxicity in mice, thus lending some support for the safe use of $C$. ambrosioides in traditional medicine.
\end{abstract}

Keywords: Chenopodium ambrosioides, Volatile oil, Oral toxicity, AST and ALT, Histopathological changes

\begin{abstract}
This is an Open Access article that uses a fund-ing model which does not charge readers or their institutions for access and distributed under the terms of the Creative Commons Attribution License (http://creativecommons.org/licenses/by/4.0) and the Budapest Open Access Initiative (http://www.budapestopenaccessinitiative.org/read), which permit unrestricted use, distribution, and reproduction in any medium, provided the original work is properly credited.

Tropical Journal of Pharmaceutical Research is indexed by Science Citation Index (SciSearch), Scopus, International Pharmaceutical Abstract, Chemical Abstracts, Embase, Index Copernicus, EBSCO, African Index Medicus, JournalSeek, Journal Citation Reports/Science Edition, Directory of Open Access Journals (DOAJ), African Journal Online, Bioline International, Open-J-Gate and Pharmacy Abstracts
\end{abstract}

\section{INTRODUCTION}

Chenopodium ambrosioides L. is a perennial plant native to tropical America and widespread in many provinces of China [1,2]. Existing studies showed that chemical composition of the volatile oil derived from $C$. ambrosioides varied with countries and areas where the plants grow [3-9]. For example, the volatile oil of the plants harvested in Egypt and Nigeria contained three 
main chemical components ( $\rho$-cymene, $\alpha$ terpinene and ascaridole) [4,5], whereas that of those in Chengdu China had two main chemical components ( $\rho$-cymene and $\alpha$-terpinene) [6].

C. ambrosioides has been used for centuries as herb medicine for anti-helmintics and healer $[10,11]$. Previous studies demonstrated that the volatile oil of $C$. ambrosioides in Chengdu of Sichuan Province of China had anti-tumor effect: it effectively inhibited proliferation of human breast cancer cells MCF-7 and hepatocellular carcinoma cells SMMC-7721 in vitro $[6,12]$, and the inhibition mechanism may be related to blocking cell cycle and inducing caspasedependent apoptosis of cancer cells [12]. Evaluations of in vivo effects of the volatile oil derived from $C$. ambrosioides are necessary to ensure safe use of the volatile oil as herb medicine in practice. However, such information is lacking.

Therefore, the aim of this study was to analyze chemical components of volatile oil of $C$. ambrosioides from Mianyang city in Sichuan Province of China. Toxicity of the volatile oil was evaluated in mice, which would provide experimental data for safe use of $C$. ambrosioides in vivo.

\section{EXPERIMENTAL}

\section{Plant materials}

One hundred plants of $C$. ambrosioides were purchased at Guanghua Village of Le'an Town, Santai County, Mianyang City, Sichuan Province of China (North: 31 $03^{\prime 4} 49.43$ ", East: $\left.104^{\circ} 58^{\prime} 37.19^{\prime \prime}\right)$

\section{Extraction of the volatile oil from $C$. ambrosioides}

According to a slightly modified steam distillation method [13], $500 \mathrm{~g}$ of the aboveground parts of the dried plants was boiled in $3 \mathrm{~L}$ water to obtain the volatile oil. The volatile oil was dried over anhydrous $\mathrm{Na}_{2} \mathrm{SO}_{4}$, filtered, sealed in a brown reagent bottle and kept at $-20{ }^{\circ} \mathrm{C}$ as reserve.

\section{GC-MS analysis}

Agilent 6890-5973 gas chromatography-mass spectrometer (GC-MS, Agilent Technologies Inc. USA) equipped with a flame ionization detector and an Agilent DB-Wax capillary column (60 $\mathrm{m} \times 0.25 \mathrm{~mm}, 0.25 \mu \mathrm{m}$ film thickness), was used in analysis of the volatile chemical components. GC conditions: oven temperature was initially 80 ${ }^{\circ} \mathrm{C}$ for $2 \mathrm{~min}$, increased at $5^{\circ} \mathrm{C} / \mathrm{min}$ to $200{ }^{\circ} \mathrm{C}$ and at $20^{\circ} \mathrm{C} / \mathrm{min}$ to $280{ }^{\circ} \mathrm{C}$, at which it was held for 5 min. Injector temperature was held at $270{ }^{\circ} \mathrm{C}$. 1 $\mu \mathrm{L}$ of the sample was injected, with split ratio of $20: 1$. Carrier gas was helium (99.999\%), and the flow rate was $1.0 \mathrm{~mL} / \mathrm{min}$. MS conditions were as followings. The temperature of electron impact ion source was set at $230^{\circ} \mathrm{C}$. The four-stage bar temperature was $150{ }^{\circ} \mathrm{C}$ and the interface temperature was $280^{\circ} \mathrm{C}$, with solvent delay of 8 $\min$. Mass spectra were obtained by scanning 35 to $450 \mathrm{~m} / \mathrm{z}$ at $70 \mathrm{eV}$.

\section{Determination of chemical components of the volatile oil}

The volatile chemical components were identified by comparing their mass spectra with the database of NIST version 11 (USA), and their relative amount was determined by calculating their GC peak areas.

\section{Animals}

Healthy male Kunming mice weighing 20 to $26 \mathrm{~g}$ were bought from Dashuo Experimental Animals Co. (Chengdu China). Use of male mice in the present study is to avoid any probability of estrogen interference with the volatile oil. Standard laboratory food bought from Dashuo Experimental Animals Co. (Chengdu China) and distilled water were applied to the mice. After the mice lived in the laboratory for 7 days and adapted to the environment, the experiments were performed according to the recommendations of the International Guidelines for the use of Animals for Scientific Purposes [14]. The experiments were approved by the animal ethics committee of Sichuan Normal University (approval no. 20180209).

\section{Toxicological test of the volatile oil in mice}

Sixty mice were randomly selected and divided into 6 groups, each group consisting of 10 mice. One group was used as control (no treatment), two groups were orally administered for 27 days with $\rho$-cymene at doses of 3 and $7 \mathrm{mg} / \mathrm{kg}$ body weight, respectively, and three groups with the volatile oil at doses of 10,25 and $40 \mathrm{mg} / \mathrm{kg}$ body weight, respectively, for the same duration. The doses of $\rho$-cymene used in this test were determined according to its relative amount $(24.25 \%)$ of the volatile oil. Body weight of each mouse was measured every 7 days. At day 28 , each mouse was weighed and then anesthetized by intraperitoneal injection with $10 \%$ chloral hydrate at the dose of $0.5 \mathrm{~mL} / 100 \mathrm{~g}$ body weight. Blood samples were drawn from abdominal aorta. Four organs (heart, thymus, kidney and 
liver) were excised and weighed. Their organ indexes were calculated according to Eq 1.

Organ index $(\%)=$ organ wet weight/body weight $\times 100$.

\section{Measurement of serum AST and ALT levels}

Blood samples were held at room temperature for blood clotting, and then centrifuged at 3000 $\mathrm{rpm}$ for $10 \mathrm{~min}$ to isolate serum. Serum AST and ALT levels were measured using AST and ALT activity measurement kits (Jiancheng Shengwu Gongcheng Co., Nanjing China), in accordance with the suggestions of the manufacturer.

\section{Histological examination}

Heart, thymus, kidney and liver of each mouse were fixed in $10 \%$ formalin, and then dehydrated in an ethanol series of increasing concentrations (v/v) $(50,60,70,80,90,95$ and $100 \%)$ and embedded in paraffin. The organs were cut into slices with $5 \mu \mathrm{m}$ thickness, and then stained with hematoxylin and eosin, and imaged under light microscope using BA200 Digital camera (Mike Audi Industrial Co., China).

\section{Data analysis}

Data were analyzed using SPSS 19.0 (SPSS Inc, USA). Least significant differences (LSD) were calculated using Microsoft Excel 2010 (Microsoft, USA). Differences were considered significant at $p<0.05$.

\section{RESULTS}

\section{Chemical composition of volatile oil from $C$. ambrosioides}

The yield of the volatile oil in extractions from $C$. ambrosioides was 0.10 - $0.16 \%$. Fourteen chemical components of the volatile oil were separated (Figure 1) and identified (Table 1), which accounted for $64.73 \%$ of the total (Table 1). $\alpha$-Terpinene and $\rho$-cymene accounted for 32.89 and $24.25 \%$, respectively, and they were main components of the volatile oil.

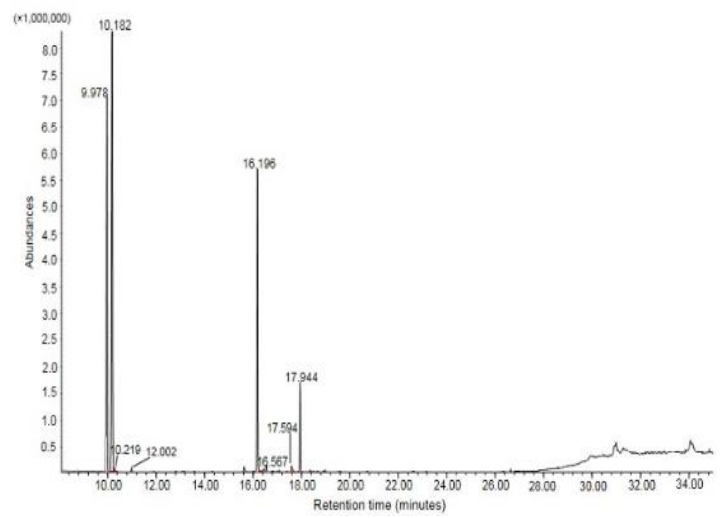

Figure 1: Chromatogram of the volatile oil from $C$. ambrosioides in Mianyang city of Sichuan Province of China

Table 1: Volatile components of $C$. ambrosioides in Mianyang city of Sichuan Province of China

\begin{tabular}{|c|c|c|c|}
\hline Compound & $\begin{array}{l}\text { Retention Time } \\
\text { (min) }\end{array}$ & $\begin{array}{l}\text { Relative } \\
\text { content (\%) }\end{array}$ & $\begin{array}{l}\text { Molecular } \\
\text { formula }\end{array}$ \\
\hline Bicyclo [3.3.1]nonan-1-ol & 9.71 & 0.11 & $\mathrm{C}_{9} \mathrm{H}_{16} \mathrm{O}$ \\
\hline $\mathrm{Y}$-Terpinene & 9.807 & 0.06 & $\mathrm{C}_{10} \mathrm{H}_{16}$ \\
\hline$\alpha$-Terpinene & 9.991 & 32.89 & $\mathrm{C}_{10} \mathrm{H}_{16}$ \\
\hline 1,4-Cyclohex-2-enedione & 10.037 & 0.41 & $\mathrm{C}_{6} \mathrm{H}_{6} \mathrm{O}_{2}$ \\
\hline$\rho$-Cymene & 10.186 & 24.25 & $\mathrm{C}_{10} \mathrm{H}_{14}$ \\
\hline D-Limonene & 10.285 & 0.45 & $\mathrm{C}_{10} \mathrm{H}_{16}$ \\
\hline$\beta$-Phellandrene & 10.37 & 0.07 & $\mathrm{C}_{10} \mathrm{H}_{16}$ \\
\hline Y-Terpinene & 10.989 & 0.54 & $\mathrm{C}_{10} \mathrm{H}_{16}$ \\
\hline o-Cymene & 12.35 & 0.18 & $\mathrm{C}_{10} \mathrm{H}_{14}$ \\
\hline Cyclooctanone & 13.027 & 0.55 & $\mathrm{C}_{8} \mathrm{H}_{14} \mathrm{O}$ \\
\hline Trans-2-caren-4-ol & 13.449 & 0.24 & $\mathrm{C}_{10} \mathrm{H}_{16} \mathrm{O}$ \\
\hline $\begin{array}{l}\text { 1-Methyl-4-(1- } \\
\text { methylethylidene)cyclohexene }\end{array}$ & 16.157 & 4.37 & $\mathrm{C}_{10} \mathrm{H}_{16}$ \\
\hline $\begin{array}{l}\text { 6-Methyl-3-(1-methyl ethyl)-7-oxabicyclo } \\
\text { [4.1.0]heptan-2-one }\end{array}$ & 16.429 & 0.14 & $\mathrm{C}_{10} \mathrm{H}_{16} \mathrm{O}_{2}$ \\
\hline Thymol & 17.602 & 0.47 & $\mathrm{C}_{10} \mathrm{H}_{14} \mathrm{O}$ \\
\hline
\end{tabular}


Toxicological effects of volatile oil from $C$. ambrosioides on mice

The 27-day oral administration with the volatile oil from C. ambrosioides at low, medium and high doses affected mice behaviors (Table 2). Ten of the total 30 mice tested became listless, 15 mice reduced in drinking water and eating food, and mice body weights decreased, in comparison with control and $\rho$-cymene treated groups (Table 2). All doses of the volatile oil tested significantly $(p<0.05)$ increased liver indexes but did not affect the indexes of heart, thymus and kidney, compared with control and $\rho-$ cymene treated groups (Figure 2). In addition, all doses of the volatile oil significantly $(p<0.05)$ increased serum AST and ALT levels, in comparison with control and $\rho$-cymene treated groups (Figure 3 ). The significant increases in serum AST and ALT levels and the liver indexes caused by the volatile oil suggest that the volatile oil may injure the liver of the mouse.

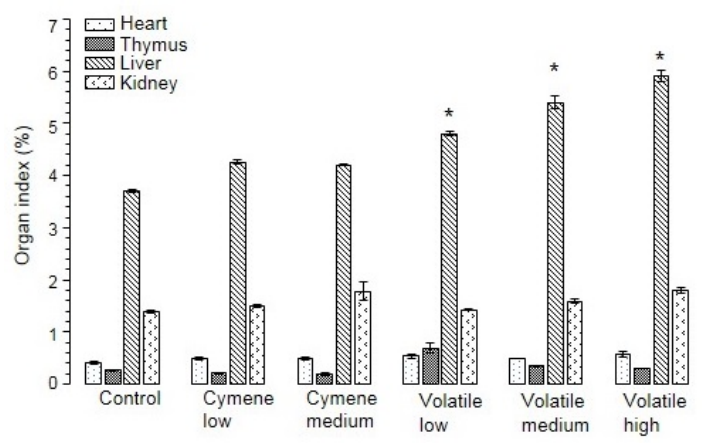

Figure 2: Effect of the volatile oil from $C$. ambrosioides on the indexes of mice organs in the 27day sub-chronic toxicological test. ${ }^{*}$ represents $p<$ 0.05

"Cymene low" and "Cymene medium" are two mice groups orally treated with $\rho$-cymene at doses of 3 and $7 \mathrm{mg} / \mathrm{kg}$ body weight, respectively. "Volatile low", "Volatile medium" and "Volatile high" are three mice groups orally treated with the volatile oil at doses of 10, 25 and $40 \mathrm{mg} / \mathrm{kg}$ body weight, respectively.

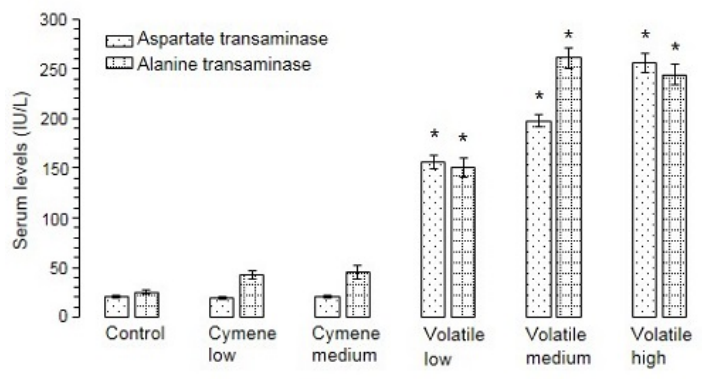

Figure 3: Effect of the volatile oil from $C$. ambrosioides on serum levels of AST and ALT in the 27-day sub-chronic toxicological test. * represents $p<$ 0.05 .

The morphology of liver tissues (Figure 4) confirmed that the volatile oil caused histopathologic changes of mice livers. The livers of mice in control group had regular cell structures and clear central vein (Figure $4 \mathrm{~A}$ ). However, increasing doses of the volatile oil induced increasing degrees of ballooning degeneration of hepatocytes and congestion of central vein in liver tissues (Figure $4 \mathrm{D}, \mathrm{E}$ and F). This result indicates that toxicity of the volatile oil on mice livers is dose-dependent.

The hearts of mice in control group had parallel arrangement of muscle fibers and centrally placed nuclei (Figure $5 \mathrm{~A}$ ). However, increasing doses of the volatile oil induced increasing degrees of inter-muscular congestions, disruptions of muscle fibers and disappearances of cross striations in heart tissues (Figure $5 \mathrm{D}, \mathrm{E}$ and $\mathrm{F}$ ). The histopathological changes of mice hearts and the increased serum level of AST (Figure 3) caused by the volatile oil demonstrate that the volatile oil damages cardiac muscle fibers.

Table 2: Effect of the volatile oil from C. ambrosioides on mice body weights in the 27-day sub-chronic toxicological test

\begin{tabular}{|c|c|c|c|c|c|c|}
\hline \multirow[t]{2}{*}{ Group } & \multirow{2}{*}{$\begin{array}{l}\text { Doses (mg/kg } \\
\text { body weight) }\end{array}$} & \multicolumn{5}{|c|}{ Body weight in the 27-day sub-chronic toxicological test (g) } \\
\hline & & 1 day & 7 days & 14 days & 21 days & 27 days \\
\hline Control & - & $22.82 \pm 0.07$ & $35.47 \pm 0.12$ & $38.94 \pm 0.13$ & $40.81 \pm 0.15$ & $43.96 \pm 0.16$ \\
\hline Cymene low & 3 & $25.01 \pm 0.29$ & $34.76 \pm 0.11$ & $36.63 \pm 0.09$ & $39.05 \pm 0.08$ & $41.48 \pm 0.05$ \\
\hline $\begin{array}{l}\text { Cymene } \\
\text { medium }\end{array}$ & 7 & $24.38 \pm 0.26$ & $33.05 \pm 0.20$ & $34.49 \pm 0.16$ & $39.72 \pm 0.13$ & $42.58 \pm 0.10$ \\
\hline Volatile low & 10 & $24.28 \pm 0.19$ & $32.02 \pm 0.21$ & $33.17 \pm 0.19$ & $36.05 \pm 0.19$ & $38.40 \pm 0.18$ \\
\hline $\begin{array}{l}\text { Volatile } \\
\text { medium }\end{array}$ & 25 & $23.82 \pm 0.06$ & $29.12 \pm 0.30$ & $31.95 \pm 0.43$ & $36.70 \pm 0.36$ & $38.91 \pm 0.35$ \\
\hline Volatile high & 40 & $23.45 \pm 0.07$ & $31.20 \pm 0.13$ & $34.53 \pm 0.10$ & $36.74 \pm 0.13$ & $38.11 \pm 0.16$ \\
\hline
\end{tabular}




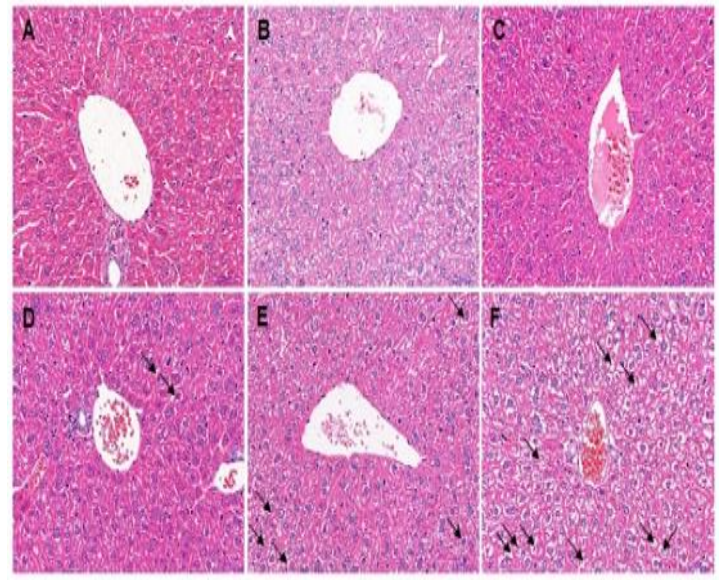

Figure 4: Histological examinations of mice livers in the 27-day sub-chronic toxicological test. Representative photomicrographs $(\times 400)$ of liver tissues: (A) control, (B) cymene low, (C) cymene medium, (D) volatile low, (E) volatile medium, (F) volatile high. Black arrows represent ballooning of hepatocytes

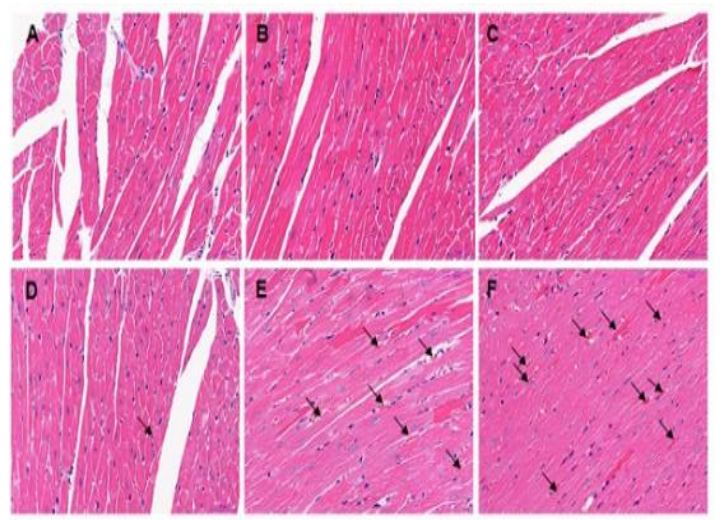

Figure 5: Histological examinations of mice hearts in the 27-day sub-chronic toxicological test. Representative photomicrographs $(\times 400)$ of heart tissues: (A) control, (B) cymene low, (C) cymene medium, (D) volatile low, (E) volatile medium, (F) volatile high. Black arrows show inter-muscular congestions

The kidneys of mice in control group had normal morphology of renal parenchyma, with welldefined tubules and glomeruli (Figure $6 \mathrm{~A}$ ). However, the increasing doses of the volatile oil caused increasing degrees of glomerular hypertrophy, tubular cell vacuolization and degeneration (e.g. cloudy swelling) in mice kidneys, with occasional tubular atrophy (Figure $6 \mathrm{D}, \mathrm{E}$ and F). However, significant histological changes of the thymuses were not observed in mice orally treated with the volatile oil, compared with control and $\rho$-cymene treated groups (Figure 7).

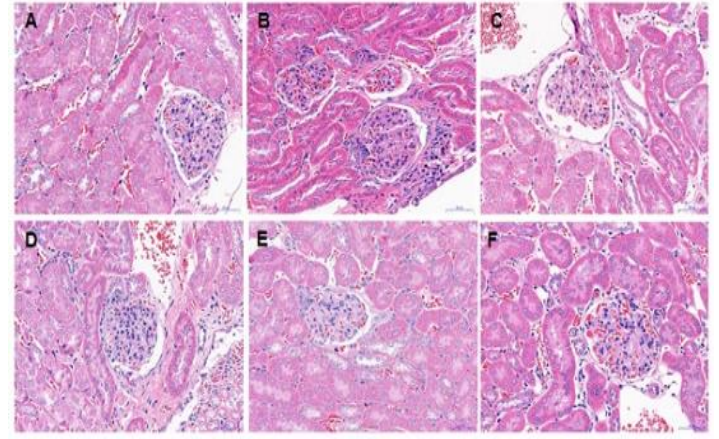

Figure 6: Histological examinations of mice kidneys in the 27-day sub-chronic toxicological test. Representative photomicrographs $(\times 400)$ of kidney tissues: (A) control, (B) cymene low, (C) cymene medium, (D) volatile low, (E) volatile medium, (F) volatile high.
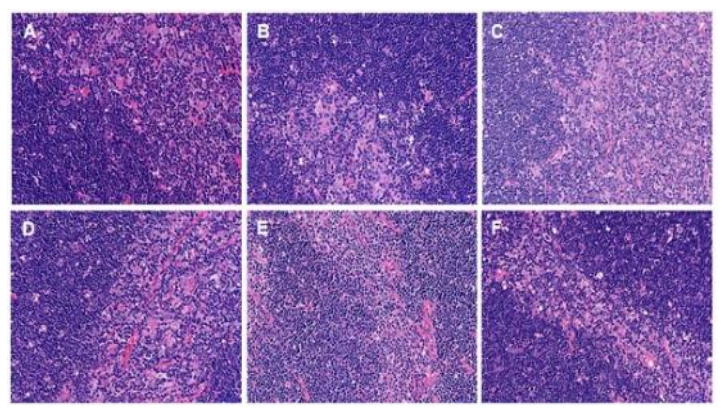

Figure 7: Histological examinations of mice thymuses in the 27-day sub-chronic toxicological test. Representative photomicrographs $(\times 400)$ of thymus tissues: (A) control, (B) cymene low, (C) cymene medium, (D) volatile low, (E) volatile medium, (F) volatile high

\section{DISCUSSION}

The volatile oil components varied with $C$. ambrosioides in different countries and provinces/states [2-9,15-18]. For example, the volatile oil of $C$. ambrosioides in Fujian Province of China contained 12 compounds, 4 main components of which were a-terpinene $(11.75$ $\%)$, $\rho$-cymene $(21.84 \%)$, ascaridole $(18.36 \%)$ and bornylene (42.63\%) [3]. The volatile oil of the plants in Guizhou Province of China had 3 main components germacrene $\mathrm{D}(14.11 \%)$, germacrene B $(11.02 \%)$ and $\beta$-caryophyllene $(12.12 \%)$ [7], whereas those in Hubei Province of China had 5 main components, which were menthol (31.331\%), a-terpinene (13.210\%), carvomenthenol (8.526\%), $\rho$-cymene $(8.343 \%)$ and 1,8-cineole $(7.417 \%)$ [8]. In this study, the volatile oil of the plants in Mianyang city of Sichuan Province of China consisted of 14 chemical components, among which, $\alpha$-terpinene and $\rho$-cymene accounted for $32.89 \%$ and 24.25 
$\%$, respectively. Previous study on the volatile oil of the plants in Chengdu city of Sichuan Province showed the relative contents of $\alpha$-terpinene and $\rho$-cymene were 21.07 and $25.88 \%$, respectively [18], suggesting that the relative contents of main volatile components slightly varied with $C$. ambrosioides in different cities of the same province. The varied chemical constitution of the volatile oil of $C$. ambrosioides in different areas might be due to the varied metabolism patterns of the plant in different environments [18].

In this study, the volatile oil significantly increased the liver index and the serum levels of liver transaminases (ALT and AST) in mice, indicating that it damages the livers. This result is consistent with literatures that increased serum ALT and AST levels can be directly linked to damage of hepatocytes $[19,20]$. Obvious histopathological changes of livers, hearts and kidneys seen in mice orally treated with the volatile oil confirmed that the volatile oil damaged these organs. The toxicity of the volatile oil in mice was dose-dependent, increasing doses of the volatile oil caused increases in serum levels of ALT and AST, the liver index and degrees of histopathological changes of mice livers, hearts and kidneys. It suggests that the volatile oil should be carefully used at adequate dose when evaluating its effect in vivo. The result that $\rho$ cymene, as one main component of the volatile oil, had less toxicity in mice than the volatile oil, is because the volatile oil is a complex of many chemical components $[9,21]$.

\section{CONCLUSION}

Fourteen volatile chemical components of $C$. ambrosioides in Mianyang have been determined by GC-MS for the first time. The volatile oil exhibit dose-dependent toxicity in mice, which suggests that the volatile oil may be safely used at doses lower than $10 \mathrm{mg} / \mathrm{kg}$ body weight However, further investigations are required to ascertain its toxicity in humans.

\section{DECLARATIONS}

\section{Acknowledgement}

This study was financially supported by Science and Technology Department of Sichuan Province of China (no. 2019YJ0501). We also acknowledged technical assistance to histological examinations of organs by Department of Pathology, Biomedicine Experiment Center, Lilai Biotechnology Co., Chengdu China.

\section{Conflicts of interest}

The authors have no conflict of interest to declare.

\section{Contribution of authors}

The authors declare that this work was done by the authors named in this article and all liabilities pertaining to claims relating to the content of this article will be borne by them. Jiao $\mathrm{Li}$ and $\mathrm{Yu}$ Wang conceived and designed the study. Jiao Li, Xiao Yang, Jing Yu, Zhimin Li, Qiuyue Deng, Yanling Cao, Xiu Chen, Hong Zhang and Yu Wang performed the experiments and collected the data. Jiao Li, Xiao Yang and Jing Yu analyzed the data. Jiao Li wrote the manuscript. All authors read and approved the manuscript for publication.

\section{Open Access}

This is an Open Access article that uses a funding model which does not charge readers or their institutions for access and distributed under the terms of the Creative Commons Attribution License (http://creativecommons.org/licenses/by/ 4.0) and the Budapest Open Access Initiative (http://www.budapestopenaccessinitiative.org/rea d), which permit unrestricted use, distribution, and reproduction in any medium, provided the original work is properly credited.

\section{REFERENCES}

1. Xu HG, Qiang S. Catalogue of invasive foreign species in China. Beijing: China Environ Sci 2004; 91-99.

2. Jardim $C M$, Jham $G N$, Dhingra $O D$, Freire $M M$. Composition and antifungal activity of the essential oil of the Brazilian Chenopodium ambrosioides L. J Chem Ecol,2008;34:1213-1218.

3. Pan X, Liang M, Chen SH. GC-MS analysis of essential oil from Chenopodium ambrosioides $L$. Chin J Pharm Anal 2007; 27(6): 909-911.

4. Harraz FM, Hammoda HM, El Ghazouly MG, Farag MA, El-Aswad AF. Chemical composition, antimicrobial and insecticidal activities of the essential oils of Conyza linifolia and Chenopodium ambrosioides. Nat Prod Res 2015; 29: 879-882.

5. Owolabi MS, Lajide L, Oladimeji MO, Setzer WN, Palazzo MC. Volatile constituents and antibacterial screening of the essential oil of Chenopodium ambrosioides L. growing in Nigeria. Nat Prod Commun 2009; 4: 989-992.

6. Wu JL, Ma DW, Wang YN. Cytotoxicity of essential oil of Chenopodium ambrosioides L. against human breast cancer MCF-7 Cells. Trop J Pharm Res 2014; 12: 929933.

Trop J Pharm Res, September 2020; 19(9): 1990 
7. He ZY, Zhou X, Wang DP, Xu BX, Liang GY. Study on the chemical constituents of the essential oil from Chenopodium ambrosioides (in Chinese). Guizhou Sci 2002; 20(2): 76-79.

8. Xiong XF, Zhang YH, Gong FJ, Nan P, Yuan P. Study on the chemical constituents of the essential oil of Chenopodium ambrosioides (in Chinese). Acta Phyto Sin 1999; 17: 244-248.

9. Song K, Wang $H Q$, LiU C, Kang J, Li BM. Chemical constituents from Chenopodium ambrosioides (in Chinese). Zhongguo Zhong Yao Za Zhi 2014; 39: 254257.

10. Pereira WS, Ribeiro BP, Sousa AIP, Serra ICPB, Mattar NS. Evaluation of the subchronic toxicity of oral treatment with Chenopodium ambrosioides in mice. $J$ Ethnopharmacol 2010; 127: 602-605.

11. Gadano AB, Gurni AA, Carballo MA. Argentine folk medicine: Genotoxic effects of Chenopodiaceae family. J Ethnopharmacol 2006; 103(2): 246-251.

12. Wang YN, Zhu XH, Ma Hi, Du RY, Li DR. The volatile oil from Chenopodium ambrosioides induced caspasedependent apoptosis of human hepatocarcinoma smmc7221 cells (in Chinese). J Chin Med Mater 2016; 39: 1124-1128.

13. Li J, He YQ, Ma DW, He B, Wang YN. Volatile allelochemicals of Chenopodium ambrosioides $L$. induced mitochondrion-mediated Ca2+-dependent and Caspase-dependent apoptosis signaling pathways in receptor plant cells. Plant Soil 2018: 1-12

14. National Research Council Committee. 2011. Guide for the Care and Use of Laboratory Animals. 8th Edition.
Washington (DC), National Academies Press (US). Available at: https://www.ncbi.nlm.nih.gov/books /NBK54050/

15. Chu SS, Feng Hu J, Liu ZL. Composition of essential oil of Chinese Chenopodium ambrosioides and insecticidal activity against maize weevil, Sitophilus zeamais. Pest Manag Sci 2011; 67: 714-718.

16. Jardim CM, Jham GN, Dhingra OD, Freire MM. Composition and antifungal activity of the essential oil of the Brazilian Chenopodium ambrosioides L. J Chem Ecol 2008; 34: 1213-1218.

17. Monzote L, Nance MR, Garcia M, Scull R, Setzer WN. Comparative chemical, cytotoxicity and antileishmanial properties of essential oils from Chenopodium ambrosioides. Nat Prod Commun 2011; 6: 281-286.

18. Huang S, Ma D W, Lu X, Zhang H. Morphological characteristics of leaf guard cells in six crops in response to the volatile stress of Chenopodium ambrosioides $L$. from different invaded habitats (in Chinese). Acta Ecol Sin, 2019, 39(5): 1517-1527.

19. Lin JK, Wang CJ. Protection of crocin dyes on the acute hepatic damage induced by aflatoxin B1 and dimethylnitrosamine in rats. Carcinogenesis 1986; 7 : 595-599.

20. Weibrecht K, Dayno M, Darling C, Bird SB. Liver aminotransferases are elevated with rhabdomyolysis in the absence of significant liver injury. J Med Toxicol 2010; 6: 294-300.

21. Amole OO, Izegbu MC. Chronic toxicity of Chenopodium ambrosioides in rats. Biomed Res 2005; 16: 111-113. 